\title{
Petrography and Geochemical Characteristic of Koohrig Intrusive Rocks in Kerman, Iran
}

\author{
Mohammad Baghkhani, Mohammad Ali Arian* \\ Department of Geology, Faculty of Science, North Tehran Branch, Islamic Azad University, Tehran, Iran \\ Email: ${ }^{\star} \mathrm{m} \_$arian@iau-tnb.ac.ir
}

How to cite this paper: Baghkhani, M. and Arian, M.A. (2017) Petrography and Geochemical Characteristic of Koohrig Intrusive Rocks in Kerman, Iran. Open Journal of Geology, 7, 683-689.

https://doi.org/10.4236/ojg.2017.75046

Received: November 20, 2016

Accepted: May 21, 2017

Published: May 24, 2017

Copyright $\odot 2017$ by authors and Scientific Research Publishing Inc. This work is licensed under the Creative Commons Attribution International License (CC BY 4.0).

http://creativecommons.org/licenses/by/4.0/

\begin{abstract}
Koohrig intrusive mass is located in the east of Rafsanjan, Kerman Province, Iran and it is part of because it has cut the sandstone, limestone, shale units and conglomerate of Upper Cretaceous. Its intrusive rock includes quartz, plagioclase and alkali feldspar and its ferromagnesian mineral which is biotite has changed into chlorite. This Intrusive mass is characterized by the presence of metamorphic geochemical studies led to the detection of granite and granodiorite and quartz monzonite rocks.
\end{abstract}

\section{Keywords}

Urumieh-Dokhtar, Metamorphism, Geochemical Studies, Calc-Alkaline, Peraluminus, Aluminum Saturation Index

\section{Introduction}

The study of igneous intrusive rocks has been concerned from long ago. The majority of granitoid intrusive rocks of Iran have been located in the area of Central Iran, Sanandaj-Sirjan zone and Urumieh-Dokhtar belt. Koohrig granitoid intrusive mass is a very small stock, its area is about Koohrig which is located in the north of village Robat from Baghin, Kerman and on the southern slopes of Mount Badamo-Arjasb. The distance of this mountain is about $7 \mathrm{~km}$ from asphalted road Rafsanjan-Kerman and the mountain Gabri is located around $5 \mathrm{~km}$ of west (Figure 1). The above mentioned Intrusive rocks have intruded in sandstone, limestone, shale units and conglomerate of Upper Cretaceous; therefore it is younger than them in terms of age. And it is known related to the Eocene age. [1] Irregular tourmaline and Lattice veins can also be seen in the intrusive rocks. Wind erosion is very intense in the south of this area. And it seems that Koohrig name is taken from the wind dunes spreading on its southern slope. The intrusive injection in host rocks has created a variety of skarn and 


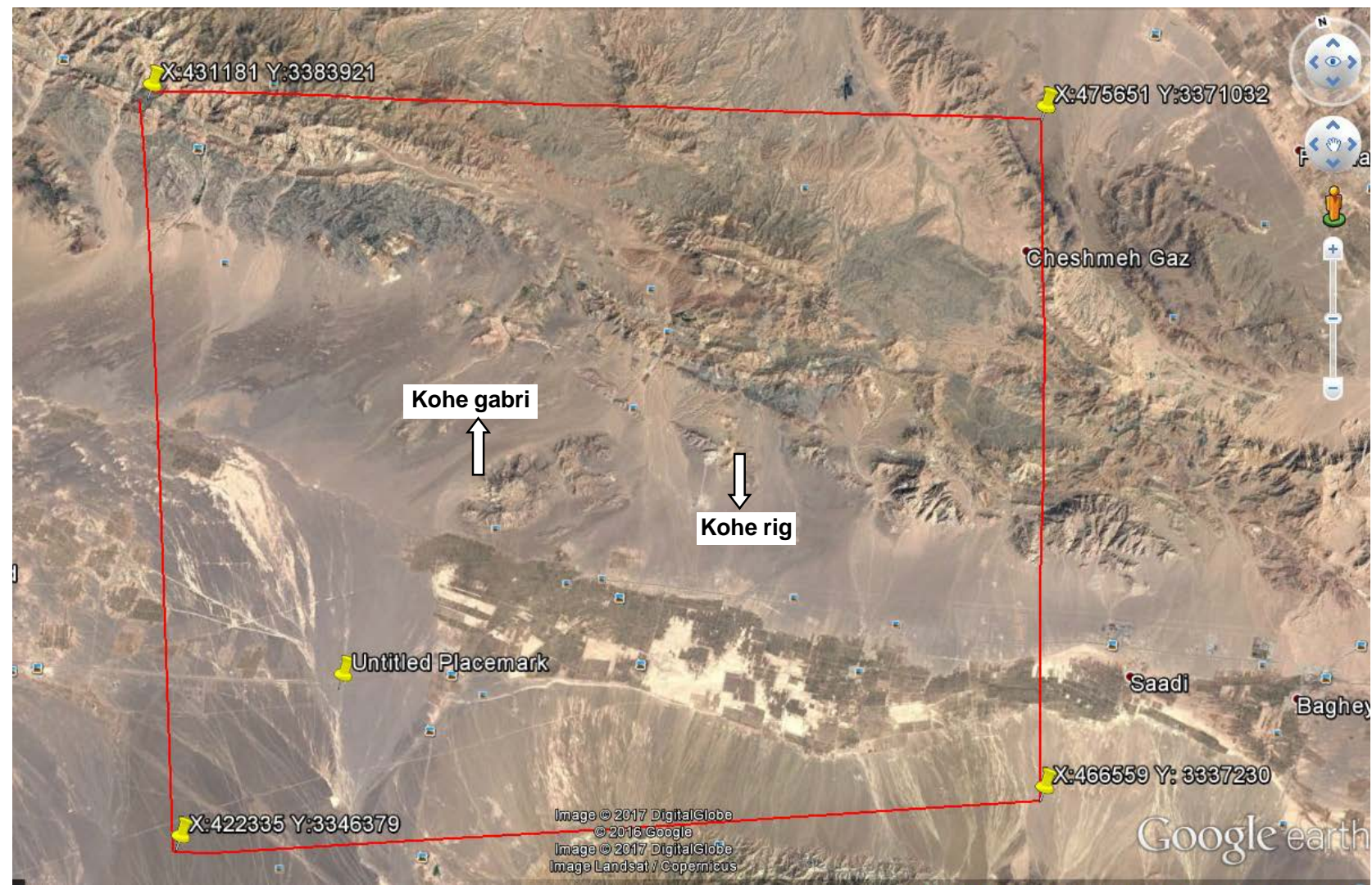

Figure 1. Position of Koohrig in satellite images of Google Earth, 2017.

hornfels. Metamorphic aureole has a range of hornfels, calc-silicate, tactit, marble and hydrothermal delay streak. [2] A number of basaltic and andesitic dikes have cut the granitoid stock in the fringe.

\section{Methods and Discussion}

\subsection{Methodology}

According to lithological variations during the field surveys, some of rock samples were obtained from various parts of Koohrig and 8 samples of granitoid and 3 samples of basaltic and andesitic dikes were chemically analyzed by ICP-OES and ICP-MS following the microscopic studies.

\subsection{Lithology}

The most important rock unit of the region is granitoid intrusive rocks. The studies have shown that the intrusive rocks almost have a homogeneous combination of granite to granodiorite with abundant granite. In manual sample it has gray granite white to pale pink and its minerals are visible by naked eye. Granitic rocks in terms of mineralogy have orthoclase, microcline, quartz, plagioclase, biotite and rarely hornblende. The main texture of the rocks is granular. Quartz makes up 30 to 35 percent of the rock minerals and they are often amorphous and in most cases have filled the space between the large crystals of plagioclase and alkali feldspar. Border of quartz crystals changes from angular, uniform to 
ridge. Alkali feldspar makes up about 15 to 20 percent of stones and its crystals are subhedral to anhedral. Connective texture from the growth of alkali feldspar with quartz (granophyric and micro-graphics texture) can be found in some samples. The feldspar metamorphosis intensity is relatively high and this mineral has become the Sericite and clay minerals. Carlsbad twin can be seen in most samples. The Plagioclase crystals can also be seen about $15-20$ percent in the board shaped or subhedral with polysynthetic twin. Plagioclase has changed to the Saussurite due to alteraction (Figure 2). One of the fundamental conditions determining the crystallization and cooling conditions of magma is texture and mineral structural connection with each other. And important results could be achieved in connection with magma crystallization mechanism by investigating the samples. In general, in granitoid rocks, the presence of plagioclase, alkali feldspar and quartz with a porphyritic and granular texture are indicative of a slow cooling condition and in balance with the environment. But creating the granophyric and micrographic textures and also zoning in plagioclase indicate the formation of non-equilibrium conditions in the crystallization environment. Presence of these textures may be the result of magma mixing. [2] [3]. Field and granite petrographic features can provide the valuable evidence to estimate the intrusive rocks depth. According to petrographic studies, Koohrig granitic stock is diagnosed as shallow type which confirmed by the following evidence: Intrusive rocks magmatic border and host rocks and metamorphic aureole surrounding rocks, lack of regional metamorphism, presence of half deep dikes related to
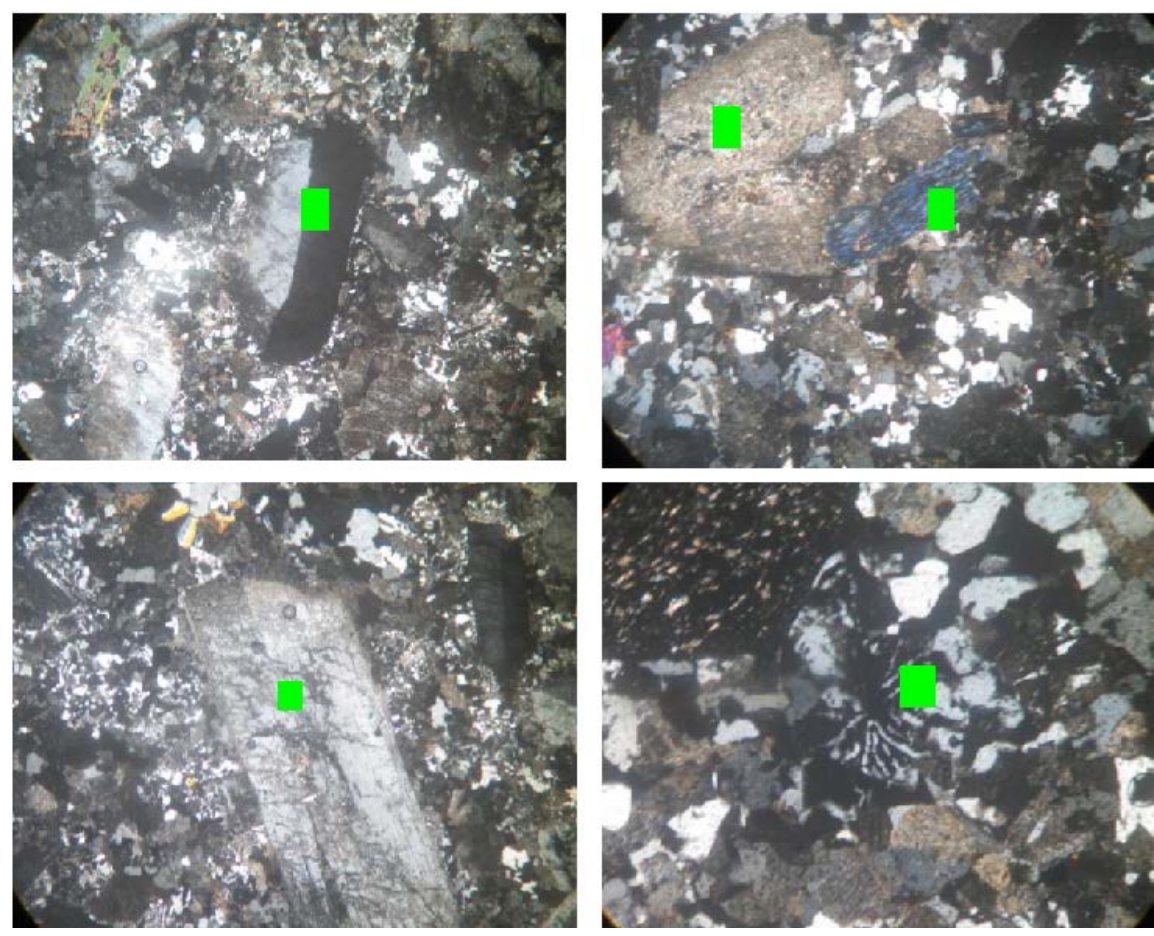

Figure 2. Thin sections images of Koohrig granite (in XPL light). (a) Chlorited biotite, (Bi) and alkaline feldspar (Kf) in the field of amorphous quartz. (b) Alkaline feldspar with Carlsbad twin. (c) Quartz with Myrmekitic texture (Qz). (d) Plagioclase phenocrysts with damaged margin (Pl). 
the final stages of differentiation and pegmatite phase in intrusive rocks with aplitic veins.

\section{Geochemistry}

At this point, we tried to identify the rock under study using the results of chemical analysis of rocks, magmatic series and tectonic environment. The samples fall within the scope of granite (Figure 3) with respect to the total alkali diagram versus silica [4] [5]. Our Sample falls within the scope of granite, granodiorite to monzonite quartz in the diagram $\mathrm{Na}_{2} \mathrm{O}+\mathrm{K}_{2} \mathrm{O} / \mathrm{SiO}_{2}$ (Figure 4). These rocks are in the range of calc-alkaline series [5] [6] to determine the magmatic series and to use the diagram $\mathrm{FeO} / \mathrm{MgO} / \mathrm{SiO}_{2}$ (Figure 5 and Figure 6) that the placement of samples in Shand diagram (Figure 7) shows this issue in the same field. [7] In determining the aluminum saturation index (ASI) that is drawn based on molar values $\mathrm{Al}_{2} \mathrm{O}_{3} / \mathrm{CaO}+\mathrm{Na}_{2} \mathrm{O}+\mathrm{K}_{2} \mathrm{O}$ [8versus $\mathrm{Al}_{2} \mathrm{O}_{3} / \mathrm{Na}_{2} \mathrm{O}+\mathrm{K}_{2} \mathrm{O}$ ], the samples are mainly in the range of peraluminus (ASI > 1) (Figure 7).

$\mathrm{SiO}_{2}$ is positioned in Harker diagrams in axis $\mathrm{x}$, and oxides of other elements are in the axis of Y. Now we examine the origin of the studied rocks and changes process in the diagrams, given the changes of oxides of main elements versus $\mathrm{SiO}_{2}$. In Harker diagrams [8], the amount $\mathrm{Fe}_{2} \mathrm{O}_{3}, \mathrm{TiO}_{2}, \mathrm{CaO}, \mathrm{MgO}, \mathrm{Al}_{2} \mathrm{O}_{3}$ should decrease with increase of $\mathrm{SiO}_{2}$ and $\mathrm{Na}_{2} \mathrm{O}$ and $\mathrm{K}_{2} \mathrm{O}$ increase in the case of affinity

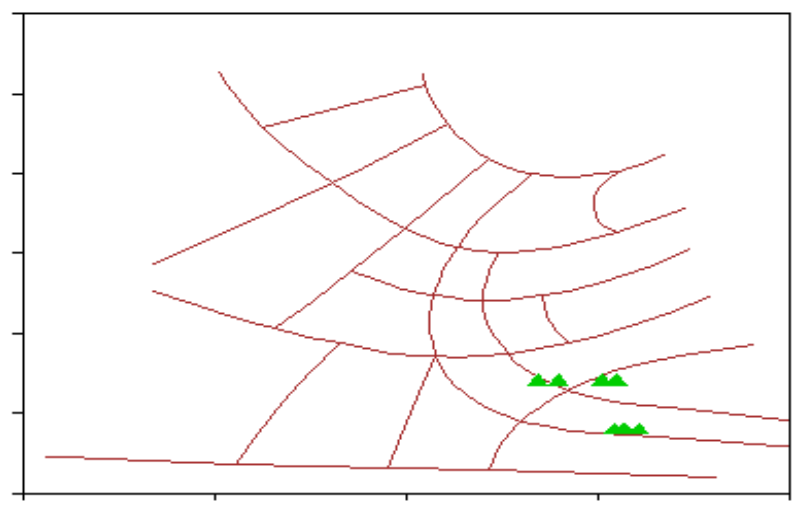

Figure 3. R1-R2 plot (Delaroohe et al., 1980).

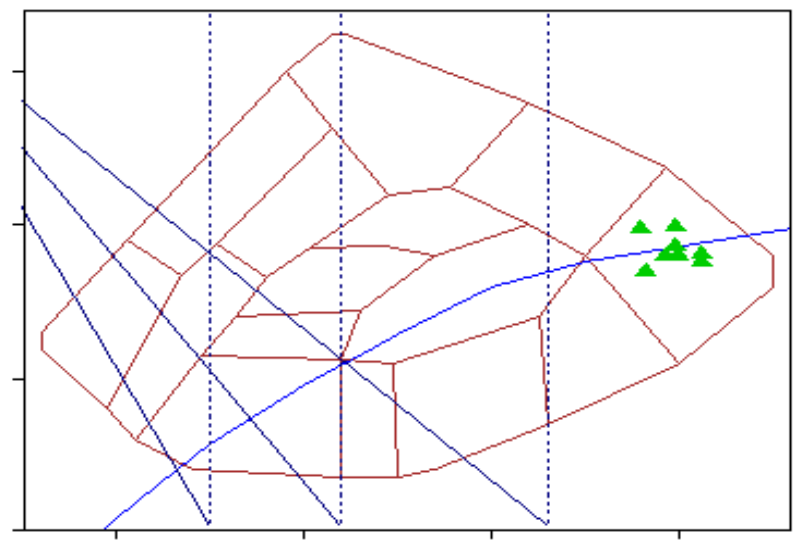

Figure 4. TAS diagram (Cox et al., 1979). 


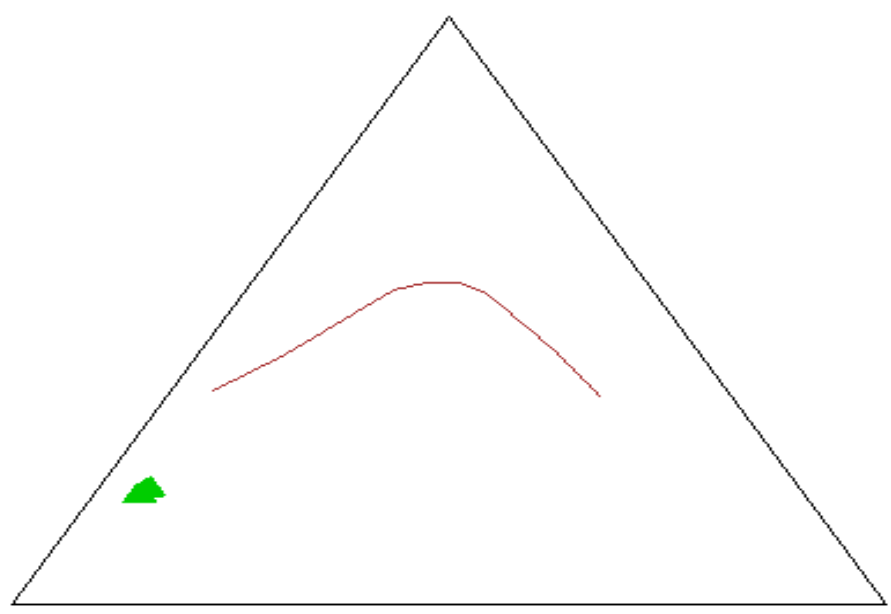

Figure 5. Determining the Koohrig granitoid magmatic series in the diagram (Miyashiro, 1974) (Irvine and Baragar, 1971).

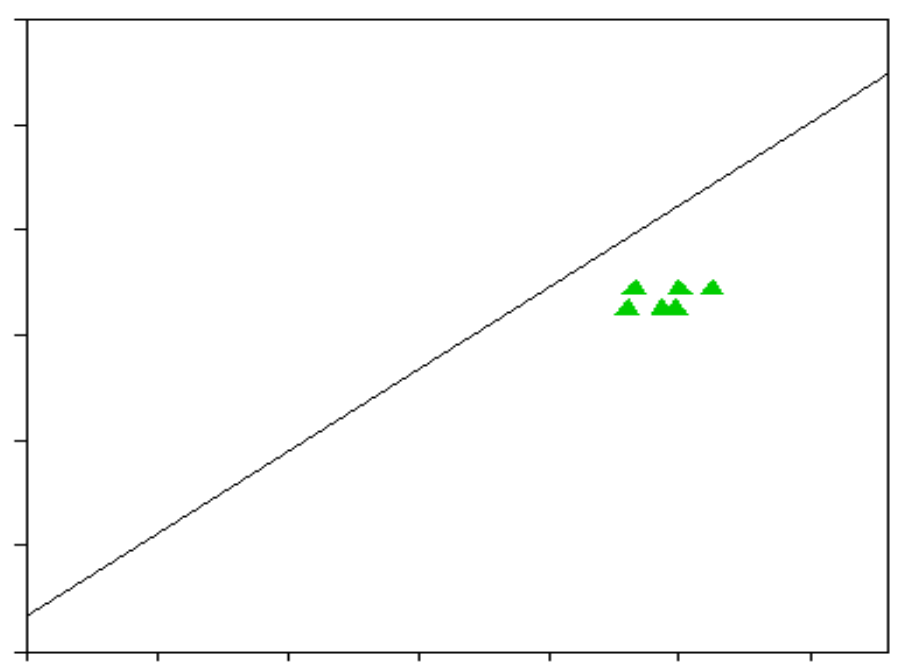

Figure 6. Position of granitoid samples of Koohrig, $\mathrm{SiO}_{2}-\mathrm{FeO}(\mathrm{t}) / \mathrm{MgO}$ plot (Miyashiro1974).

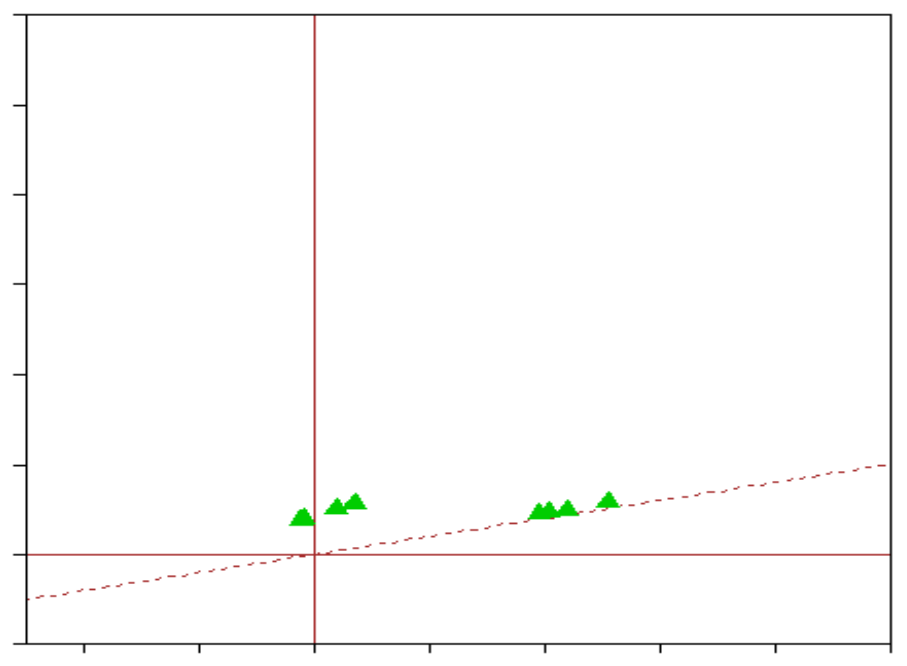

Figure 7. Position of the samples in the diagram of aluminum saturation index (ASI) (Shand, 1943). 
to the primary magma as well as partial melting or differentiation, otherwise there is no affinity between samples or the secondary changes is the reason for this that should be found. It should be noted that any linear trend established in the Harker diagrams is not subject to rocks formation from parent magma and caused by differentiation and other phenomena [9] can also be effective in inducing this processes. According to Harker diagramsplotted for samples (with the exception of basalts) the oxides of main elements such as $\mathrm{Fe}_{2} \mathrm{O}_{3}, \mathrm{MgO}, \mathrm{MnO}$, $\mathrm{CaO}$ and $\mathrm{Al}_{2} \mathrm{O}_{3}$ can be seen with the significant increase of $\mathrm{SiO}_{2}$ in downward changes. The changes are justified by the crystallization of mafic minerals (augite, green or brown hornblende, biotite, magnetite, titano-magnetite, titanite and plagioclase) (Figures $8(\mathrm{a})-8(\mathrm{e})$ ).

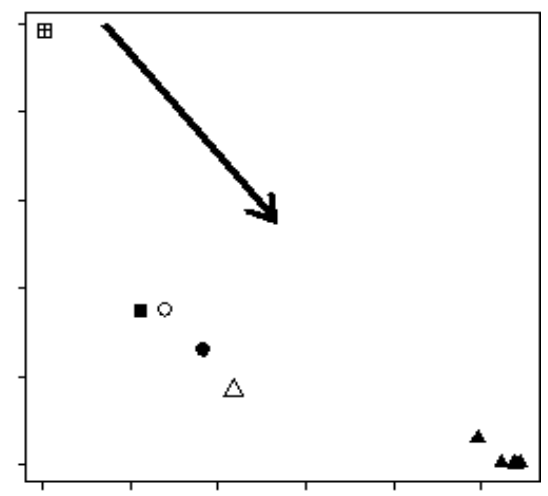

(a)

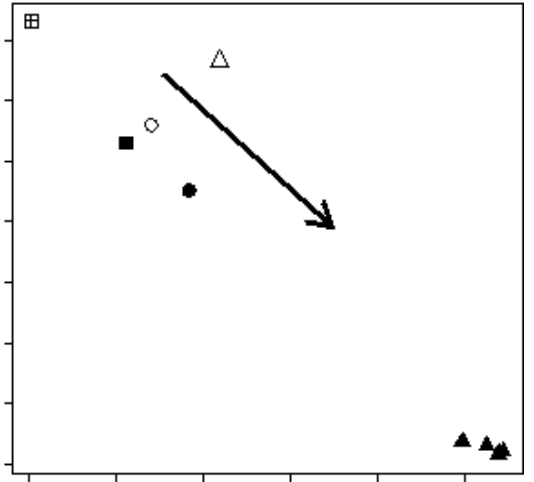

(c)

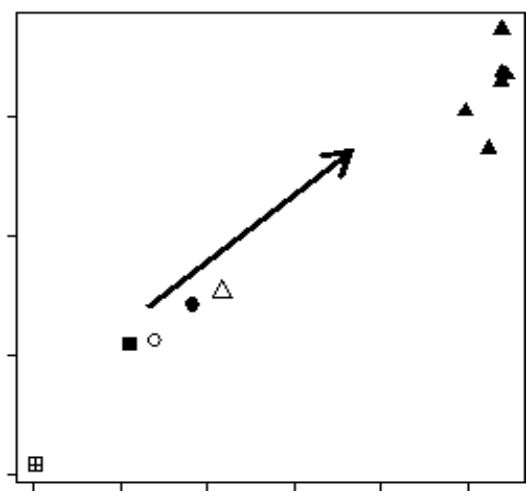

(b)

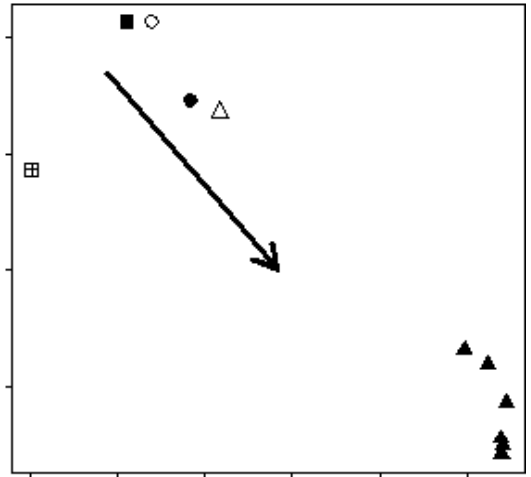

(d)

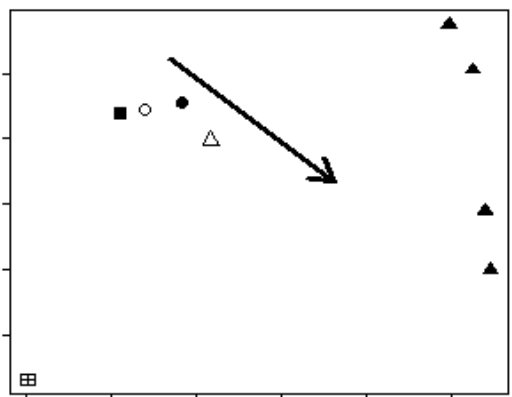

(e)

Figure 8. (a) Diagram of $\mathrm{SiO}_{2}$ versus $\mathrm{K}_{2} \mathrm{O}$ in the Koohrig rocks; (b) Diagram of $\mathrm{SiO}_{2}$ versus $\mathrm{MgO}$ in the Koohrig rocks; (c) Diagram of $\mathrm{SiO}_{2}$ versus $\mathrm{Fe}_{2} \mathrm{O}_{3} \mathrm{t}$ in the Koohrig rocks; (d) Diagram of $\mathrm{SiO}_{2}$ versus $\mathrm{CaO}$ in the Koohrig rocks; (e) Diagram of $\mathrm{SiO}_{2}$ versus $\mathrm{Al}_{2} \mathrm{O}_{3}$ in the Koohrig rocks. 


\section{Conclusions}

- Koohrig granitoid mass is located in the east of Rafsanjan, Kerman Province, Iran and it is part of Urumieh-Dokhtar magmatic arc. This platonic mass has cut the Cretaceous sedimentary rocks and is younger than Cretaceous.

- Koohrig can be divided into three sections in terms of lithological composition:

1) Main rocks that contains a combination of granite and granodiorite.

2) Diabase and andesite dikes in the region.

3) Metamorphism halos surrounding the igneous mass.

- According to the drawn petrology diagrams, this result could be obtained that Koohrig gravitational plutonic rocks are taken from magma and differentiation though little has been occurred in them.

- Geochemical studies of this igneous mass suggest a composition containing granite to granodiorite and quartz monzonite for the rocks.

- Magmatic series of the rocks is of calc-alkaline and it is located within the aluminum saturation in terms of aluminum saturation index (ASI).

\section{References}

[1] Dimitrijevic, M.D. (1973) Geology of Kerman Region: Institute for Geological and Mining Exploration and Institution of Nuclear and Other Mineral Raw Materials, Beograd-Yugoslavia, Geological. Survey of Iran, Rept Yu/52.

[2] Boztug, D., Arehart, G.B., Platevoet, B., Harlavan, Y. and Bonin, B. (2007) High-K, Calc-Alkaline I-Type Granitoids from the Composite Yozgat Batholith Generated in a Post-Collisional Setting Following Continent-Oceanic Island Arc Collision in Central Anatolia, Turkey. Mineralogy and Petrology, 91, 191-223. https://doi.org/10.1007/s00710-007-0196-2

[3] Hibbard, M.J. (1981) The Magma Mixing Origin of Mantled Feldspars. Mineralogy and Petrology, 76, 158-170. https://doi.org/10.1007/BF00371956

[4] Cox, K.G., Bell, J.D. and Pankhurst, R.J. (1979) The Interpretation of Igneous Rocks. George Allen and Unwin, London, 450 p. https://doi.org/10.1007/978-94-017-3373-1

[5] De La Roche, H., Leterrier, J., Grandclaude, P. and Marchal, M. (1980) A Classification of Volcanic and Plutonic Rocks Using R1R2-Diagram and Major Element Analyses-Its Relationships with Current Nomenclature. Chemical Geology, 29, 183-210. https://doi.org/10.1016/0009-2541(80)90020-0

[6] Miyashiro, A. (1974) Volcanic Rock Series in Island Arcs and Active Continental Margins. American Journal of Science, 274, 321-355. https://doi.org/10.2475/ajs.274.4.321

[7] Irvine, T.N. and Baragar, W.R.A. (1971) A Guide to the Chemical Classification of the Common Volcanic Rocks. Canadian Journal of Earth Sciences, 8, 523-484. https://doi.org/10.1139/e71-055

[8] Shand, S.J. (1943) Eruptive Rocks; Their Genesis, Composition, Classification, and Their Relation to Ore Deposits, with a Chapter on Meteorites (Revised Second Edition). Hafner Publishing Co., New York.

[9] Hibbard, M.J. (1995) Petrography to Petrogenesis. Prentice Hall, Englewood Cliffs, New Jersey. 
Submit or recommend next manuscript to SCIRP and we will provide best service for you:

Accepting pre-submission inquiries through Email, Facebook, LinkedIn, Twitter, etc. A wide selection of journals (inclusive of 9 subjects, more than 200 journals)

Providing 24-hour high-quality service

User-friendly online submission system

Fair and swift peer-review system

Efficient typesetting and proofreading procedure

Display of the result of downloads and visits, as well as the number of cited articles Maximum dissemination of your research work

Submit your manuscript at: http://papersubmission.scirp.org/

Or contact ojg@scirp.org 